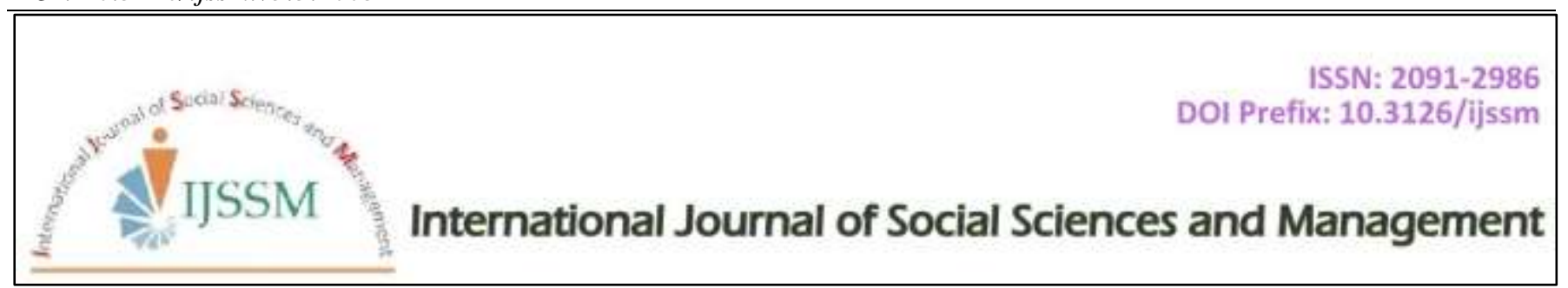

Research Article

\title{
Consideration of Official Village Head Given Obligation as Mediator in Solving Land Rights Dispute among Villagers in Indonesia
}

\author{
La Ode Munawir ${ }^{1 *}$, Rachmad Safa'at ${ }^{1}$, Tunggul Anshari Setia Negara ${ }^{1}$, Imam Koeswahyono ${ }^{1}$ \\ ${ }^{1}$ Law faculty, Brawijaya University, Malang, Indonesia.
}

\begin{abstract}
Village head act as mediator in solving villager's dispute. However, on the other hand, village head act as implementer of village governance. Therefore, questions arise concerning why village head should become the mediator in solving villagers' dispute, concerning mediator should be neutral side in reconciliate all related parties. Method used in this study was normative legal research with philosophical approach, concepts, cases, history and statute approach. Theories and concepts used in this dissertation includes legal objectives theory, authorization theory, dispute solving theory. Results and discussion: Consideration of village head given obligation as mediator in solving villager's land rights dispute, village head act as implementer of village governance, with the authority given by statute and authority based on origins, village head acts as the village reconciliation judge. The existence of village governance was very close with the villagers itself starting from the head's involvement in land registration process until it was presume that village head was knowledgeable concerning land history within the village border. However, on the other hand, village head has many authorities that should be implemented.
\end{abstract}

Keywords: mediator; village head; dispute.

\section{Introduction}

Village head act as the mediator in solving villager's dispute. Questions would arise concerning why village head should become the mediator in solving villager's dispute, concerning mediator position was supposed to be the neutral in reconciliating all parties. According to Soetardjo Kartohadikoesoem, villages in Java were like "small republics", whereas village governance was built on the behalf of people sovereignty. Trias politica that was implemented in modern state-nation was also implemented traditionally in village governance. Villages in Java has known Lurah (village head) and its apparatus as the executive body, village meeting (rembug Desa) as legislative body that holds the utmost power, and Morokaki Council that acts as judicative body for judicial matter and sometimes playing the role as board of consideration for executives. (Direktorat Pemerintahan Desa dan Kelurahan Direktorat Jendral Pemberdayaan Masyarakat dan Desa Departemen dalam Negeri Jakarta, 2007).

\section{Cite this article as:}

L.O. Munawir et al. (2018) Int. J. Soc. Sc. Manage. Vol. 5, Issue-3: 83-88. DOI: 10.3126/ijssm.v5i3.20034

$1 *$ Corresponding author

La Ode Munawir,

Law faculty, Brawijaya University, Malang, Indonesia.

Email: munawir_ktc@yahoo.com

Peer reviewed under authority of IJSSM

(C) 2018 International Journal of Social Sciences and Management

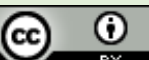

This is an open access article \& it is licensed under a Creative Commons Attribution 4.0 International License (https://creativecommons.org/licenses/by/4.0/) 
However, things that currently occurs in government of Office Village only includes two institution, executive body run by village head and legislative body run by Village Consultative Body and also village head act as mediator which then raise the questions whether village head was an expert in mediating and whether village head can be a fair arbiter. Principles written in village regulation that village government organization was based on "professionality" principle was the principle which prioritize expertise under ethic code and statute provisions. Based on this principle, implementer should be in accordance with its expertise, which raise the question whether village head was an expert in mediation matter. Implementer meant in this passage would means village apparatus, village head and village consultative body, and therefore village government implementer should be principle-driven in carrying out his task according to his expertise.

Villager's disputes occurs most of the time, and thus this study would limit the dispute type with the focus on issue regarding land rights. During land registration, sometimes there was dispute among villagers concerning who has the rights to registrate the land. Land act as the location or place for human to work for a living. From philosophical perspective, land has the fundamental relationship with human. In religious terms, "Inna lillahi wa inna ilaihi rajiun" means that human came from Allah and return to Allah, by means, was another religious term of from land will return to land. Human creation process also started from the land (soil/ground) which means that relationship between human or the people with land was eternal in nature.(Julius Sembiring, 2011)

The land was considered as valuable asset for the people. Therefore, land administration should be implemented in the smallest governance unit of village office or subdistrict office and recorded in village's book. (Waskito, 2014). This statement means that village's governance was involved in the process of land registration, by recording it into the book, village head also involved in reconciliation of proprietary dispute.

\section{Problematic Definition}

Based on this background, problematic definition of this study was why village head was given obligation as mediator in solving land rights dispute among villagers.

\section{Objectives}

Objectives of this study was to describe, to analyze and to discover about argumentation concerning obligation/duty of village head as mediator in solving land rights dispute among villagers.

\section{Method}

This research was using normative legal research method with several approaches such as historical approach, concept approach, statute approach and philosophical approach. Analysis toward legal material was conducted in prescriptive manner, by using deductive-inductive reasoning toward vague norms by using legal interpretation.

\section{Results and Discussion}

Philosophical aspect, philosophical consideration concerning why village always become an interesting topic to dicuss were because village is the seed of Indonesia and also that village existed first. Therefore, village should be used as the basic and parts of later administration. Village with older public administration, should become the key point in implementation of government, development and society affairs (Direktorat Pemerintahan Desa dan Kelurahan Direktorat Jendral Pemberdayaan Masyarakat dan Desa Departemen dalam Negeri Jakarta, 2007). According to Koento Wibisono Siswomihardjo, knowledge philosophy should be directed toward components that acts as pillars for knowledge existence, which are ontology, epistemology and axiology (Siswomihardjo et al., 2012).

Ontology aspect, knowledge ontology covers the essence of knowledge, the essence of truth and reality, truth and reality mention here concerning the truth in solving disputes among villagers through village head. Village head is the implementor of village government's administration for villagers affairs, also village head acts as mediator to solve dispute among villagers. Epistemology, epistemologically, solving dispute among villagers was by using institution within the village itself, either those old institution or new institution to peacefully solve any dispute among villagers. Axiology aspect, questioning whether the duty of village head as mediator has already in accordance with legal objective given that village head has two roles, as implementor of village government and as mediator.

As the miniature of Indonesia, village has become the closest political arena for relationship between the people and those in power (village apparatus) whereas village apparatus was also part of the state bureaucracy who has state duty, by running bureaucray in village level, implementing development programmes, delivering administrative service toward the people (Direktorat Pemerintahan Desa dan Kelurahan Direktorat Jendral Pemberdayaan Masyarakat dan Desa Departemen dalam Negeri Jakarta, 2007).

A village head was not allowed to be in charge of other position, so that he could direct and give all his effort for the course of village government, to improve prosperity of villagers. Village head did not only act as a head, but also a leader. He should know and lead to obtain success in his tasks (Surianingrat, 1985). Up to date, mechanism of solving dispute through mediation still lives among the people, and it can be said as tradition in solving disputes, which generally mediated by village head, small village head or even religious figures (Bintoro, 2016). Consideration of village head with obligation to act as 
mediator in solving land rights dispute was in line with literature source, statute and author 's observation as follows:

\section{Village Head as Village Government Implementer}

Village government is the implementer for government affairs and local people interest in the governmental system of Unitary State of the Republic of Indonesia (Additional recommendation was article 1 clause (3) Statute No 6 of 2014). The one who implement village government affairs in line with village regulation was village head or as called with other title. Village Head is one of the implementer of village government. Village head is the first person that carry the heavy duty and obligation, because he is the implementer and held accountable for every government, development, and societal affairs, including accompaniment, peaceful and order ( Syafrudin, \& Na,a, 2010). Also, village head as the implementer of village government carry authority in his rights and obligation of duty.

Village head is the formal leader because he was officially appointed from the central government. Implementation of village government would be more success if its implementation was no only based on regulations, but also supported by personal relationship, mental relationship and leadership (Sumeru, 2016). A leader has the ability to disperse his influence over others so that they would voluntarily follow the leader under conscious mind and without force. The art and knowledge of leadership should be learnt and mastered by village head and implemented thereafter. Therefore, village head become an informal leader ( Sumeru, 2016).

Political democracy was represented by village head's leadership that carry legitimation and deep rooted, an accountable and responsive village government, transparant village implementation, political control of BPD toward village government, inclusion and deliberation through village meeting, people participation, and active citizenship (Muqowan, 2017). Village statutes, at least contain about 22 articles concerning village head, stating various aspects of it such as: (i) the duty, rights and authority of village head; (ii) accountability of village head; (iii) prohibition for village head, (iv) village head election, and (v) work elimination of village head (Yasin, 2015). Village head is the main organ of village government who carry the duty, rights and authority as mentioned in Article 26 subsection (1), subsection (2) and subsection (3).

The concept of village government was the closest government to the people at the lowest level (lowest level in public institutional system of Republic of Indonesia). Therefore, even the smallest village government would still carry its strategic role and position in public service and people's empowerment. To be able to empower the people and implementing service function, village should be empowered and empowering in any sectors (Fadli, 2011). Empowering in this matter would related with all sectors including eliminating villager's dispute and thus the role of village government as the lowest and the closest government to the people was highly needed. Village is governmental organization that directly related to social, cultural and economic life of the people. The term "under" was having similar meaning with the term "front" and "close". The term "front" means that village has direct relationship with the people, either in governance, public service, development, empowerment and societal matter. Most Indonesian people would always refers to village government when they look for public service and solving various social matter. Therefore, village government and apparatus, which were different than regional government and apparatus, should be prepared to serve the people for 24 hours without rest, absent or day off. While the term "close" means that administrative and geographically speaking, village government and the people would be able to closely related to one another. In social meaning, "close" means that the village was becoming one with the routine social cultural life of the local community (Eko, 2015).

Village head is the single ruler in village government. Together with its apparatus, he is the village guardian. Village head is the household implementer in village level, and he also the implementer of government affairs. But still, in completing his task, he still had his own limitation, and cannot follow his own personal interest (Eko, 2015). Although village head act as single ruler in village government with its own limitation, if one matter did not part of his expertise than he did not have the competence to implement it, such as in solving villager's dispute concerning matter beyond his expertise. Village head as the representative of village government should pay attention concerning the implemented land strategy which covers mastery, proprietary, land use and land utilization, that relevant or in line with Four Principles of Land Management suggested by National Land Affairs Agency Republic of Indonesia since 2004, that are: First, contributing in improving people welfare and realizing new sources of people's welfare. Second, contributing in improving fairer collective life order in its relation with land utilization, use, governance and proprietary. Third, contributing in assuring the sustainability of societal and nationalistic system of Indonesia, by giving most access to the future generation regarding economic sources of the people particularly the land. Fourth, contributing in creating harmonious collective life order by addressing various land dispute in all parts of the nation, and implementing management system which no longer create disputes and conflicts in the future (Nugroho, 2016).

Previously, a village head did not allowed to be in charge of other position, so that he could direct and give all his effort for the course of village government, to improve prosperity 
of villagers. Village head did not only act as a head, but also a leader. Therefore, he should know and learn about leadership. So that he could obtain success in completing his tasks (Surianingrat, 1985).

\section{Village Authority Based on Origins Rights and Local- scaled Authority}

Authority is the important element act as the rights own by a village to run its own household. From this understanding, it was clear that in discussing about authority did not only pay attention toward power obsessed by the ruler but also should pay attention toward the subjects who implement and who receive power (Silahuddin, 2015). Authority is the basic of implementation concerning post's task, whereas implementation of post's task can be discovered from activity or acts, either intern or extern, public law act or private law act (Sudarsono, 2013). Village Authority: Article 1 subsection 12 Domestic Affairs Minister Regulation Number 44 of 2016, authority own by villages would includes authority based on origins rights, villagescale local authority, authority appointed by the government, provincial government or regency/municipal government and other authority appointed by government, provincial government or regency/municipal government in accordance with statute provisions.

Combination between recognition and subsidiarity principles in village statue has result different village definition compare to the previous definition. Village was defined as unity of legal community with teritorial border and authorized to regulate its own governmental affairs and local people interest based on people initiative, origin rights and or acknowledged traditional rights in the governmental system of Unitary State of Republic of Indonesia. Village statute has placed the village as the mixed organization between people ( Ra'is, 2017). Village authority was based on recognition and subsidiarity principles, not based on decentralization principle. Village authority did not follow the distribution scheme or transfer of some authority portion from regency/municipal government but more tend to recognition and subsidiarity schemes on behalf of local community, directly regulated in village statute. Based on these schemes, there were two main type of village authority:

"(a) origin authority was acknowledged by the nation: managing asset (natural resources, community land, cash land Desa) in village jurisdiction, forming village governmental structure by accomodating original structure, solving dispute in customary way and preserving the local custom and culture, (b) attributive authority was used to arrange and regulate local people's interest (village): development planning and village planology, forming structure and village's government organization, held village head election, forming village representative agency, managing village budget, forming social institution, developing village owned corporation and others"(Direktorat Pemerintahan Desa dan Kelurahan Direktorat Jendral Pemberdayaan Masyarakat dan Desa Departemen dalam Negeri, 2007).'”

Authority based on origin rights is the right of living inheritance and was village's or villager's initiative according to development of people's life ( illage Minister Regulation, Regional Development Backward, and Transmigration of the Republic of Indonesia No. 1 of 2015. Local authorities at the village level will include, article 1 clause 3 ). Village local authority concerning society matters would include: a) maintain area's safety, order and quiet life for the villagers, b) maintain tolerance among villagers, c) maintain peace, handling conflict and conduct mediation in the village, d) preserve and develop 'gotong royong' among villagers. ( illage Minister Regulation, Regional Development Backward, and Transmigration of the Republic of Indonesia No. 1 of 2015. Local authorities at the village level will include, article 13).

Village Head's Authority in Solving Land Rights Dispute among Villagers

People thinks that village head is people's father who lead the lifestyle within community. Therefore, in this kind of life, village head has the obligation to maintain legal life within the community and assure that this legal provision was implemented as proper as possible (Munir, 1996). Kleintjes suggested that: The village has been given authority to manage their household according to its will, either in law enforcement and its management the village did not completely free in managing their household. The village was given autonomy by referring to regulation made by the governor general, regional head or autonomy government, appointed by ordinance (Surianingrat, 1985).

Authority by post, either Minister or Head of Institution, Governor and or Regent/Meyer would able to, at any time, give task toward village head, by delivering "task related document" toward village head, in order to aid its government implementation, public service, development and people empowerment. Task giver hold the authority and responsibility, while the village was in the position to managed and assist the task completion. Concerning the task, task-giver would send financial cost for the village ( Eko, 2015). This sort of task assignment was based on several considerations:

1) Government faced limited resources in implementing governmental tasks and development that reach all parts of community and households;

2) Village was closer, knowledgeable and able to reach the service for the people;

3) Task implementation in lower level was more efficient (low cost) and effective (target oriented) 
if it was conducted by the village than central government apparatus. Type of assignment toward the village was quite vary such as issuance several type of official statement and introduction letter, official statement concerning land rights and many others.

Local Authority Initiative in Julubori village was the history of nation mandate for the villages. Village would conduct village court when Julubori village head conduct execution regarding land dispute. There were 41 (forty one) case of civil law and those can be solved in 3 (three) years, through mediation with village head of Julubori. This proverb can become one way to mediate the problem before it occurs "kalah jadi abu, menang jadi arang (loosing become ashes, winning become charcoal). One of the case was able to reach the court, but ended in peace reconciliation. It was dispute concerning land propriety rights and the accepted decision was to equally divided all 31 ha land for all parties involved and thus each party has identical portion of the land." (Eko, 2015).

Provision from Article 26 subsection 4 letter (k) suggested that village head has the obligation to solve villager's dispute. The reality showed that village head solve villager's dispute particularly those concerning civil law. Although land or agrarian law was also included within domestic administration law, village head was involved in the reconciliation process of land rights dispute, such as in case approach of Atambua Class I B district court verdict No. 2/PDT.G/2015/PN Atb and Supreme High Court decision No. 2265/K/Pdt/2014. Before being recorded as official, both decisions were confirmed in the village office through village's reconciliation judge taken be village head.

\section{Role of Village Head in Land Registration and Case Approach}

Reason why village head was being involved in land rights dispute among villagers was because village head has its role in land registration process: a). Reminding the people to instal land mark pole/stake, b) Present during measuring process, c) Reminding the people to maintain the safety of basic point technique (KDKN), d) Act as member of land assessor committee (committee A). Research result of Waskito with the title "Peran Kepala Desa/Lurah dalam Persertifikatan Tanah (Role of Village Head/Subdistrict Head in Land Certificate Process)" showed that village head still did not recognize his role in land registration, land measurement and land assessor committee (Waskito, 2014). Therefore, village head cannot be said reliable concerning land registration matter.

\section{Conclusion}

Consideration of village head given obligation as mediator in solving land rights dispute among villagers, village head act as implementer in village government, and authority given by the statute and authority based on origin rights has existed before. Village head as village reconciliation judge exists in village government as the institution that stand very close to the people and thus village head was considered to be suitable to solve villager's dispute. Village head was involved in land registration process so that he was assumed to be knowledgeable concerning land history within the village's border but he was also burdened with various authority to be implemented.

\section{References}

Bintoro RW (2016) Kajian Ontologis Lembaga Mediasi di Pengadilan. Yuridika 1: 121 - 142.

Direktorat Pemerintahan Desa dan Kelurahan Direktorat Jendral Pemberdayaan Masyarakat dan Desa Departemen dalam Negeri. (2007) Naskah Akademik Rancangan Undang-Undang tentang Desa. Jakarta.

Eko S (2015) Regulasi Baru Desa Baru Ide dan Misi dan Semangat Uu Desa. Jakarta : Kementerian Desa, Pembangunan Daerah Tertinggal, Dan Transmigrasi Republik Indonesia.

Fadli M, Hamidi J and Lutfi M (2011) Pembentukan Peraturan Desa Partisipatif Head To A Good Village Governance. Malang : UB Press.

Munir M (1996) Pendayagunaan Pengadilan Negeri Sebagai Lembaga Untuk Menyelesaikan Sengketa Dalam Masyarakat (Studi pilihan hukum yang berkaitan dengan penyelesaian sengketa tanah di kabupaten Bangkalan Mudara, Surabaya). Disertasi Universitas Airlangga Program Pascasarjana.

Muqowan A (2017) Kembali Ke Mandat Hasil Pengawasaan DPD RI atas Pelaksanaan UU nO 6 Tahun 2014 Tentang Desa. Jakarta : Komite I DPD RI.

Nugroho A, Sutaryono and Subroto T (2016), Relasi Kuasa Dalam Strategi Pertanah Di Desa Prigelan. Yogyakarta : STPN Press.

Peraturan Menteri Desa, Pembangunan Daerah Tertinggal, Dan Transmigrasi Republik Indonesia Nomor 1 Tahun 2015 Tentang Pedoman Kewenangan Berdasarkan Hak Asal Usul Dan Kewenangan Lokal Berskala Desa.

Ra'Is DU (2017) Kebijakan Pemberdayaan Masyarakat Dalam Persfektif Asas Rekognisi Dan Subsidiaritas Undang- Undang desa Nomor 6 Tahun 2014. Reformasi 1: 29-46.

Sembiring J (2011) Tanah Dalam Perspektif Filsafat Ilmu Hukum, Mimbar Hukum 2: 394-405.

Silahuddin (2015) Kewenangan Desa dan Regulasi Desa. Jakarta : buku I.Kementrian Desa, Pembangunan 
Dearah Tertinggal dan Transmigrasi Republik Indonesia.

Siswomihardjo KW, Mudhofir A, Wahyudi I, Mustansyir R, Soeprapto S, Abas HM and Tjahyadi S (2012). Filsafat Ilmu Sebagai Dasar pengembangan Ilmu Pengetahuan, Yogyakarta: Liberty Yogyakarta

Sudarsono (2013) Sekilas Tentang Wewenang Dan Penyelagunaan Wewenang (dalam perspektif hukum administrasi Negara. Malang: Universitas Wisnuwardhana malang Press.

Surianingrat B (1985) Pemerintahan Administrasi Desa dan Kelurahan. Jakarta: Aksara Baru.
Syafrudin HA and Naa S (2010) Republik Desa, Pergulatan Hukum Tradisional dan Hukum Modern dalam Desain Otonomi Desa, Bandung : P.T.Alumni.

Undang-Undang No 6 Tahun 2014 Tentang Desa

Waskito (2014) Peran Kepala Desa/Lurah Dalam Pensertifikatan Tanah, Jurnal pertanahan, I: 103120.

Yasin M (2015) Anotasi Undang-Undang No. 6 Tahun 2014 Tentang Desa. Jakarta : Pusat Telaah Dan Informasi Regional 